\title{
CYTOTOXICITY AND MORPHOLOGICAL ANALYSIS OF CELL DEATH INDUCED BY Bothrops VENOMS FROM THE NORTHEAST OF ARGENTINA
}

\section{Bustillo S (1, 2), Lucero H (1), Leiva LC (2), Acosta O (3), Kier Joffé EB (4), Gorodner JO (1)}

(1) Tissue Culture Sector, Regional Institute of Medicine, Northeast National University, Corrientes, Argentina; (2) Laboratory of Biological Biochemistry, Northeast National University, Corrientes, Argentina; (3) Laboratory of Pharmacology, Northeast National University, Corrientes, Argentina;(4) Ángel H. Roffo Oncology Institute, University of Buenos Aires, Buenos Aires, Argentina.

ABSTRACT: Bothrops snake venoms have been proved toxic to a variety of cell types, in both in vivo and in vitro models. Studies on the pharmacological actions of Bothrops venoms from Argentina are relatively scarce and the direct action of the crude venoms has not been assessed using cell culture models. In this work, we investigated the cytotoxicity of crude venoms from $B$. alternatus and $B$. diporus in a skeletal muscle (C2C12) cell line, which is commonly used as a model for studying the myotoxic action of snake venom. Both venoms $(1.25-50 \mu \mathrm{g} / \mathrm{mL})$ induced an early and significant decrease in cell viability. The cytotoxic concentration $50\left(\mathrm{CC}_{50}\right)$, determined three hours after exposure, revealed that $B$. diporus venom was significantly more cytotoxic $\left(\mathrm{CC}_{50}: 2 \mu \mathrm{g} / \mathrm{mL}\right)$ than $B$. alternatus $\left(\mathrm{CC}_{50}: 5.8 \mu \mathrm{g} / \mathrm{mL}\right)$. To investigate the cell death mechanism involved, myoblast cells were examined by phase contrast microscopy and after acridine orange and ethidium bromide fluorescence staining, respectively. Our data clearly demonstrated that an apoptotic mechanism mediated this cell line destruction. The current study aimed to provide new information on the cytotoxicity mechanisms of Argentine Bothrops snake venoms on a skeletal muscle cell line.

KEY WORDS: Bothrops alternatus, Bothrops diporus, cytotoxicity, C2C12, apoptosis.

CONFLICTS OF INTEREST: There is no conflict.

FINANCIAL SOURCE: Northeast National University and CONICET.

\section{CORRESPONDENCE TO:}

SOLEDAD BUSTILLO, Facultad de Ciencias Exactas y Naturales y Agrimensura, Av. Libertad, 5450, Campus Deodoro Roca, (3400) Corrientes, Argentina. Phone: +54 03783 457996. Fax: +54 03783 473930. Email: soledadb@exa.unne.edu.ar. 


\section{INTRODUCTION}

In snakebites cases, envenomations are associated with an amazing variety of pathophysiological manifestations, which differ among the various groups of snakes and even within the same genera and species (1). Acute skeletal muscle damage is a frequent manifestation in envenomations induced by Elapidae and Viperidae snake families $(1,2)$.

The majority of snakebites in northeastern Argentina are caused by $B$. alternatus (yarará grande) and $B$. diporus (yarará chica), reptiles that belong to the Viperidae family (3-5). Their venoms induce predominantly local myotoxicity, characterized by myonecrosis often associated with other effects, such as hemorrhage, blistering and edema, in a complex pattern of local tissue damage $(6,7)$. Myonecrosis is an important medical complication of snakebites that can lead to drastic sequelae including permanent tissue loss, disability, amputation or myoglobinuria and acute renal failure, a frequent cause of death in snakebite victims (8).

Previous works from our group demonstrated in vivo myotoxic effects of Bothrops alternatus venom in a rat gastrocnemius muscle. Muscular necrosis, hemorrhage among muscular fibers and edema were described $(9,10)$.

Although in vivo experiments are adequate techniques to investigate the action of snake venoms on the overall muscle tissue scenario, these models preclude the analysis of some specific aspects of the toxin action on muscle cells. In that sense, as an approach to the characterization of the mechanisms involved in myotoxicity, cultured cells $(11,12)$ or isolated enzymes - such as myotoxic PLA $A_{2}$ - (13-17) have been evaluated as targets for crude venoms.

On the other hand, in vitro cell culture model and screening assays for cell death have become important tools to determine the chronology of events resulting in apoptosis (18).

Despite the great advances in the understanding of morphological and biochemical alterations associated with chemically induced cell injury, the in vitro cytotoxic effects of Botrhops venoms from Argentina, at the cellular level, have not been characterized yet.

$\mathrm{C} 2 \mathrm{C} 12$ is a cell line that exhibits most of the characteristics of normal myoblastic cells (19). These cells are commonly used as a model for studying muscle cell growth and differentiation. On the other hand, they are also a suitable target for the cytotoxic action of crude venoms or isolated enzymes, as proven by previous studies 
$(11,12,17,20-23)$. Therefore, this cell culture is an appropriate in vitro model system to evaluate the myotoxicity and the events involved in the cell death caused by Bothrops venoms.

In the current work we compared the toxic potency between both venoms on myoblast cell line and, in order to elucidate a putative direct cytotoxic action, we analysed the cytotoxicity and morphological features of cell death induced by $B$. alternatus and $B$. diporus venoms on the mouse myoblast continuous cell line, C2C12.

\section{MATERIAL AND METHODS}

\section{Venoms}

$B$. alternatus and $B$. diporus crude venoms were collected from several snakes from northeastern Argentina, vacuum dried and kept at $-20^{\circ} \mathrm{C}$.

\section{Cell Culture}

C2C12 (CRL-1772, ATCC) is a subclone murine skeletal muscle cell line derived from mouse myoblast cells obtained from normal adult $\mathrm{C} 3 \mathrm{H}$ leg muscle. This cell line rapidly differentiates and produces extensive contracting myotubes that express characteristic muscle proteins. Cytolysis was assessed in undifferentiated myoblasts. Cells were grown in $25 \mathrm{~cm}^{2}$ flasks using minimum essential medium (MEM - Gibco, Argentina), supplemented with 10\% fetal bovine serum (FBS - Sigma-Aldrich, USA), gentamicin (1 mg/L) in a humidified atmosphere with $5 \% \mathrm{CO}_{2}$ at $37^{\circ} \mathrm{C}$.

\section{Cytotoxicity Assays: $\mathbf{C C}_{50}$ Determination}

For cytotoxicity assays, undifferentiated myoblasts were harvested from subconfluent monolayers after exposure to trypsin/EDTA at $37^{\circ} \mathrm{C}$. The resuspended cells were seeded in 96-well microplates, at an approximate initial density of 1 to $2 \times 10^{4}$ cells per well, on the same growth medium. When monolayers reached $80 \%$ subconfluence, different concentrations of Bothrops venoms, diluted in sterile culture medium supplemented with $5 \%$ of FBS (ranging from 1.25 to $50 \mu \mathrm{g} / \mathrm{mL}$ ), were added to the cell cultures (after aspirating their medium) in a total volume of $200 \mu \mathrm{L} /$ well. After three hours of incubation, cell viability was quantified by crystal violet staining, non-adherent cells were removed by washing twice with phosphate-buffered saline (PBS) and adherent cells were fixed with methanol:glacial acetic acid (3:1 ratio), and 
stained with $0.5 \%$ crystal violet in $20 \%(\mathrm{v} / \mathrm{v})$ methanol. The dye was released from the cells by addition of ethanol: glacial acetic acid (3:1 ratio). The optical density of the released dye solution was determined at $620 \mathrm{~nm}$. Cytotoxicity was determined by comparing the resulting absorbances with the mean absorbance of the control wells (without venom, considered as $100 \%$ viability), and was expressed as percentage of cell viability. The $50 \%$ cytotoxic concentration $\left(\mathrm{CC}_{50}\right)$ is defined as the quantity of venom generating $50 \%$ of cell viability, compared to the control. The values of the percentages of cell viability were plotted against venom concentrations, and $\mathrm{CC}_{50}$ was determined. Experiments were carried out in quadruplicate.

\section{Cell Morphology Analysis}

Morphological alterations and cell damage were qualitatively investigated using a light phase contrast microscope (Axiovert $40 \AA$, Carl Zeiss Argentina), and the photos were taken with a digital camera (Canon CCD 2272×1704, Argentina).

\section{Apoptosis Assay}

In order to determine whether $B$. alternatus and $B$. diporus venoms induce apoptosis in this myoblast cell line, cells were grown on coverslides and treated with $10 \mu \mathrm{g} / \mathrm{mL}$ of Bothrops venoms for 30 minutes at $37^{\circ} \mathrm{C}$ and $5 \% \mathrm{CO}_{2}$. This concentration, higher than the $\mathrm{CC}_{50}$ obtained after the three-hour incubation, was chosen bearing in mind the short exposure time in this apoptosis assay. After incubation, cultured myoblast were washed twice with PBS and gently mixed with a mixture of acridine orange (AO) $(1 \mu \mathrm{g} / \mathrm{mL})$ and ethidium bromide (EB) $(1 \mu \mathrm{g} / \mathrm{mL})$ dye solution for one minute as described by Spector et al. (24). Coverslides were applied to the slides; afterwards, the sections were observed and photographed under a fluorescence microscope (Axioskop 40®/Axioskop $40 \mathrm{FL} 囚$, Carl Zeiss, Argentina).

\section{Statistical Analysis}

Data represent the mean \pm standard deviation (SD) of at least four replications. Statistical significance was tested by one-way ANOVA and Tukey (HSD) and pvalues inferior to 0.05 were considered significant. 


\section{RESULTS}

\section{Cytotoxicity}

The toxicity of Bothrops venoms was assessed quantitatively by a crystal violet dye uptake assay. After three hours of treatment, a dose-dependent cell death was induced by both venoms, being cell viability significantly inhibited, regarding the untreated control, at all venom concentrations assayed (Figure 1 - A). Interestingly, a clear difference between the toxic potency of both Bothrops venoms on the $\mathrm{C} 2 \mathrm{C} 12$ cell line was detected even at the highest concentrations tested, being $B$. diporus venom significantly more toxic $(p<0.05)$. In that sense, the linear relationships $(r=$ 0.9946 and $r=0.9592$ for $B$. alternatus and $B$. diporus, respectively) allowed us to determine the cytotoxic concentration of venoms that reduced cell viability by $50 \%$, $\mathrm{CC}_{50}$ (Figure 1 - B). The obtained values $\left(\mathrm{CC}_{50}: 2 \mu \mathrm{g} / \mathrm{mL}\right.$ for $B$. diporus and $\mathrm{CC}_{50}: 5.8$ $\mu \mathrm{g} / \mathrm{mL}$ for $B$. alternatus) confirmed the major cytotoxicity activity exhibited by $B$. diporus venom. 


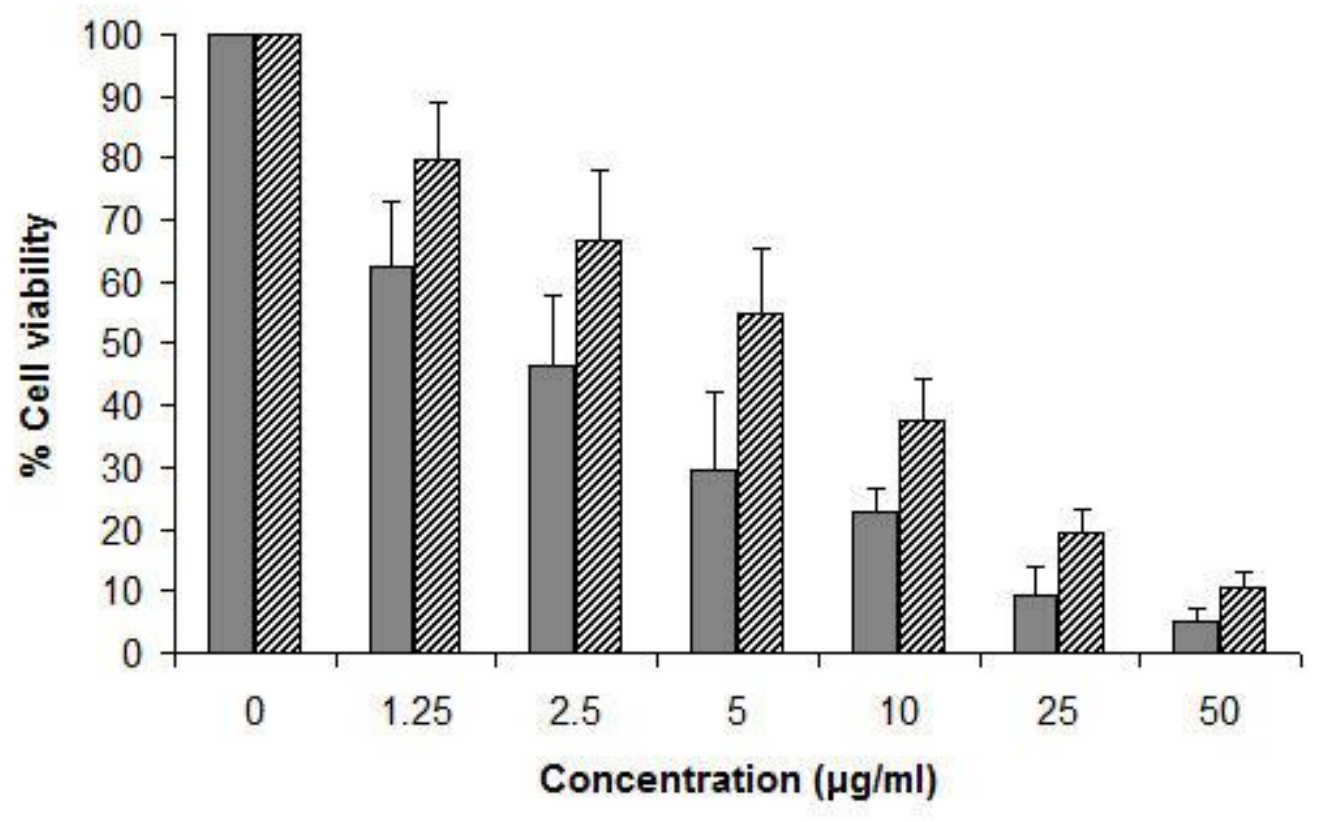

B alternatus $\square \mathrm{B}$ diporus

A

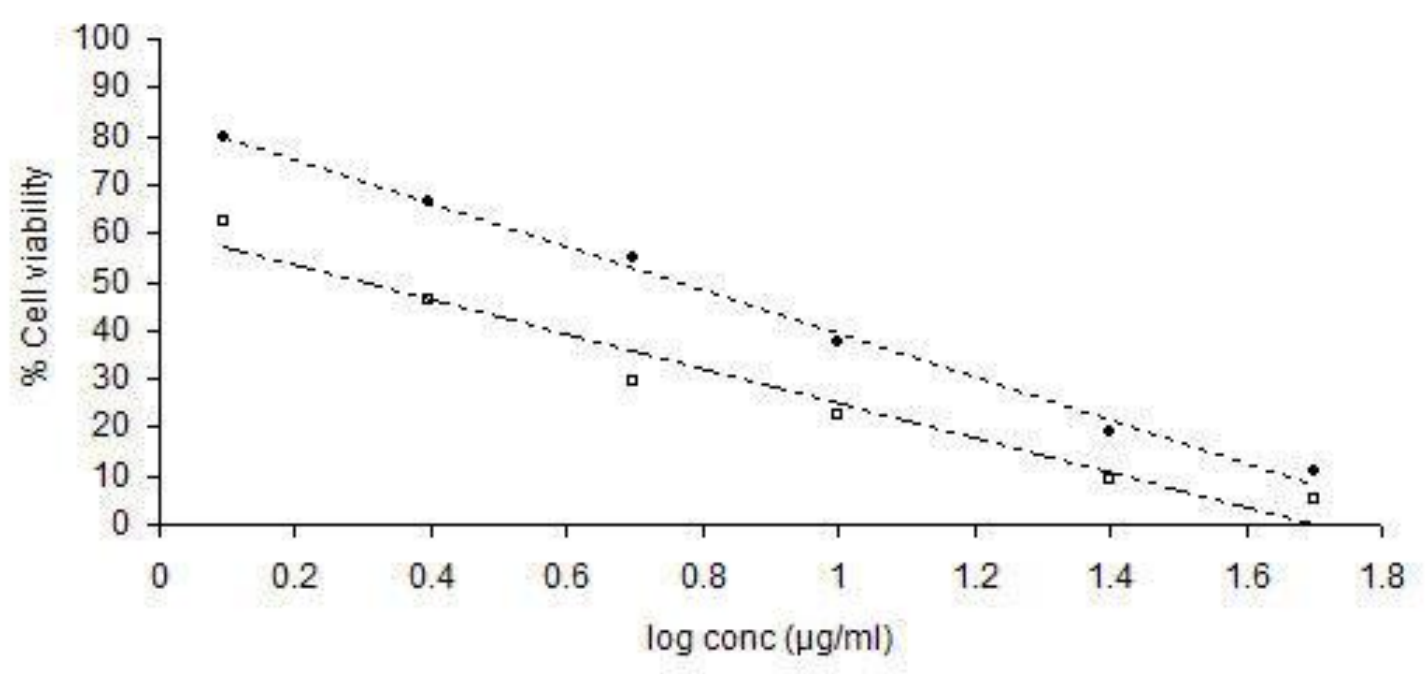

- B alternatus $\square$ B diporus

Figure 1. Decrease in cell viability of $\mathrm{C} 2 \mathrm{C} 12$ cells three hours after the inoculation with Bothrops crude venoms (1.25 to $50 \mu \mathrm{g} / \mathrm{mL})$; exposure assessed by a crystal violet cell uptake assay (A). The mean of the control group, treated with medium alone, was taken as $100 \%$ of dye uptake value. Data (mean \pm SD) are representative of three independent experiments carried in quadruplicate. Determination of cytotoxic concentration $50\left(\mathrm{CC}_{50}\right)$ (B).

${ }^{*} p<0.05$ : $B$. alternatus and $B$. diporus versus control group; $\dagger p<0.05$ : $B$. alternatus versus $B$. diporus venom (one-way Anova and Tukey). 


\section{Cell Morphology}

To assess alterations of cell morphology subsequent to treatments, $\mathrm{C} 2 \mathrm{C} 12$ cells were grown on glass coverslides. Untreated $\mathrm{C} 2 \mathrm{C} 12$ cells were homogeneously distributed on cultured field; they exhibited a thin and elongated shape, observed by phase-contrast microscopy (Figure 2 - A, B and C). However, after incubation with10 $\mu \mathrm{g} / \mathrm{mL}$ of $B$. alternatus venom - a concentration that produced detectable changes the occurrence of various morphological abnormalities was recorded. The 30-minute alterations, induced by the treatment, included reduction of nuclear sizes, which often displayed diverse degrees of chromatin condensation. Cell rounding and some areas devoid of cells were also noticed in the same culture (Figure $2-D$ ). Furthermore, cell shrinkage and the formation of blebs on cell surface finally resulted in the generation of apoptotic bodies (Figure $2-E$ and F). Similar observations were obtained with $B$. diporus venom treatment (data not shown).
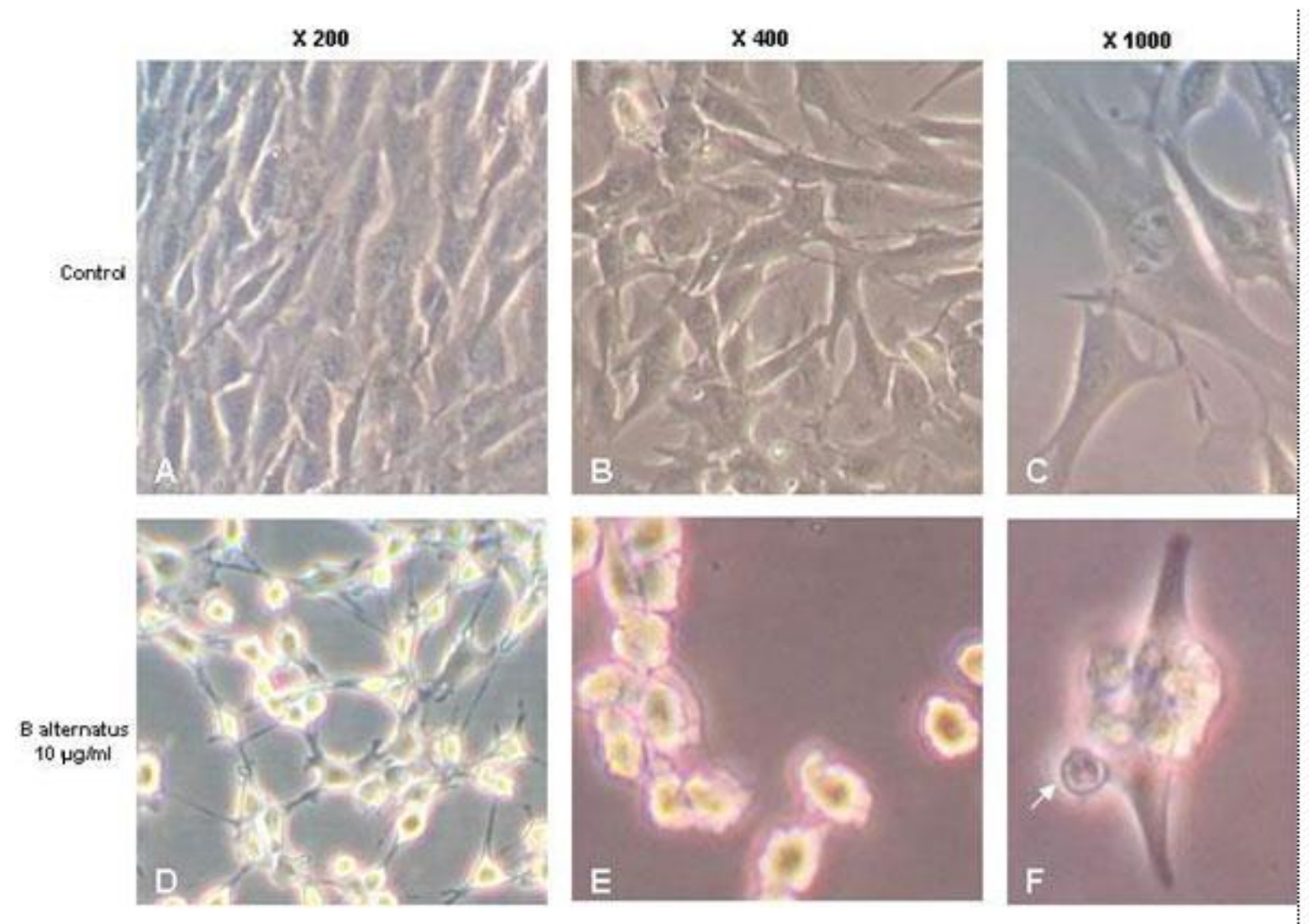

Figure 2. Morphological characterization under phase contrast microscopy of cell death induced by $B$. alternatus venom in murine $\mathrm{C} 2 \mathrm{C} 12$ cells. Control cells (respectively 200, 400 and 1,000x) (A, B and C). Irregularity in shape and cellular detachment in treated cells (200x) (D). Cell shrinkage and formation of blebs on the cell surface (400x) (E). Apoptotic body (arrow, 1,000x) (F). 


\section{Apoptosis Assay}

In order to determined whether $B$. alternatus and $B$. diporus venoms induced morphological alterations that could be attributed to an apoptotic mechanism, myoblast cells were treated with the venoms for short periods and then stained with the nucleic acid-binding fluorochromes, acridine orange and ethidium bromide. Control untreated cells exhibited a green fluorescence, due to exclusion of ethidium bromide but not of acridine orange. Viable cells showed a light green nucleus with intact structure and presented punctuate orange red fluorescence in the cytoplasm, representing lysosomes stained by acridine orange (Figure 3, control). After 30 minutes of incubation with $10 \mu \mathrm{g} / \mathrm{mL}$ of Bothrops venoms, typical features of apoptosis were observed. Apoptotic cells exhibited a bright green nucleus (showing condensation of chromatin), dense green areas and evident membrane blebbing (Figure 3, B. alternatus and B. diporus). Some condensed nuclei were stained with orange fluorescent dye with ethidium bromide, indicating compromised membrane integrity, probably produced after the first stages of nuclear apoptotic condensation, mainly in the case of $B$. diporus venom (Figure 3, B. diporus). 

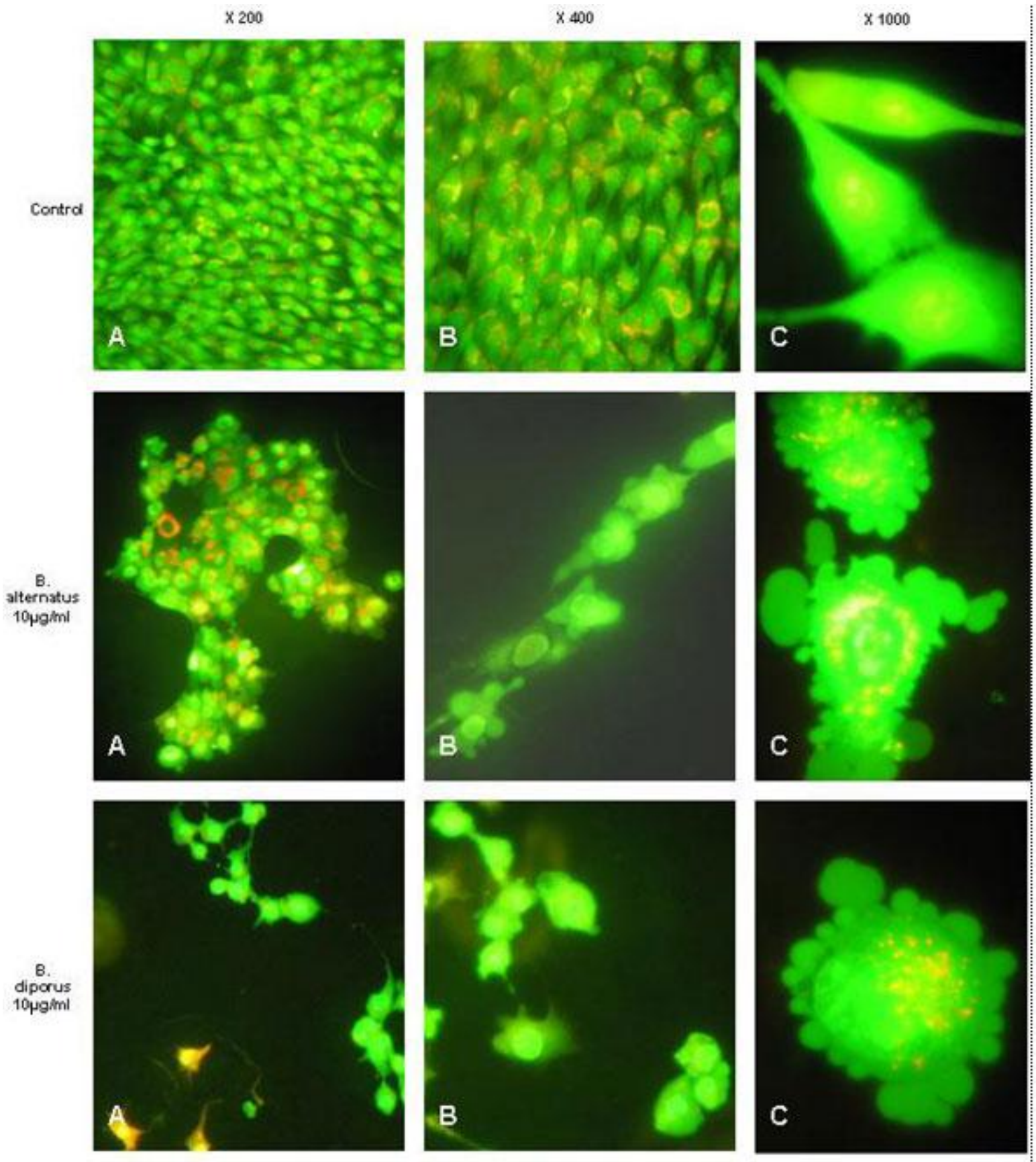

Figure 3. Representative photomicrographs showing cell shrinkage, chromatin condensation and the formation of blebs on the cell surface associated with apoptosis assayed by acridine orange and ethidium bromide staining. Cell lines were grown on coverslides and treated for 30 minutes with $10 \mu \mathrm{g} / \mathrm{mL}$ of Bothrops venoms.

\section{DISCUSSION}

In vivo experiments are adequate models to investigate the action of snake venoms on muscle tissue. However, these models preclude the analysis of specific aspects related to the action of myotoxins on muscle cells. Cell culture models have been 
utilized aiming at the dissection of discrete steps in muscle cell damage; keeping in mind that extrapolation to in vivo conditions must be done with caution (25). Studies employing a variety of cell lines in culture showed that snake venoms display a relatively broad cytotoxic spectrum $(11,12,26,27)$. Similar observations were made with several toxins, mostly myotoxic $\mathrm{PLA}_{2} \mathrm{~S}$ isolated from viperid snake venoms (15, $17,21,23,28-30)$.

Thus, due to the possibility of manipulating cellular processes and mechanisms in vitro, myoblast cell culture allows the study of specific aspects of venoms action on these cells.

In this study, we demonstrated a direct cytotoxic effect of $B$. alternatus and $B$. diporus snake crude venoms on a skeletal muscle myoblast cell line. The decrease in cell viability, observed following exposure to Bothrops venoms, suggest a cytotoxic activity of both venoms in vitro. Our observations fully agree with experimental evidence of rapid and drastic degenerative events that occur in skeletal muscle fibers in vivo (10). Interestingly, our data are very similar to those reported by Oliveira et al. (27) concerning these two venoms on Vero cells $\left(\mathrm{CC}_{50}\right.$ : $16.5 \mu \mathrm{g} / \mathrm{mL}$ and $\mathrm{CC}_{50}: 14.4$ $\mu \mathrm{g} / \mathrm{mL}$ for $B$. alternatus and $B$. diporus, respectively). Therefore, in both cell lines, $B$. diporus venom has demonstrated major toxic potency.

Several works demonstrated that crude elapid and crotalic venoms induce apoptosis in different cell types $(11,31,32)$ or isolated enzymes from bothropic venoms, such as phospholipases $A_{2}(33,34)$ and metalloproteases $(35-38)$. Cell death is currently the subject of a considerable number of investigations. This interest stems, in part, from the potential of understanding oncogenesis and from the possibility of exploiting cell death program for therapeutic purposes (39-41).

In this work, we studied the in vitro process of cell death caused by $B$. alternatus and B. diporus venoms on $\mathrm{C} 2 \mathrm{C} 12$ cell line, observing that a very short exposure of cells to these venoms results in marked morphological changes consistent with an apoptotic mechanism of cell death, such as chromatin condensation and nuclear fragmentation, cell shrinkage and bleb formation on cell surface, which finally results in the generation of apoptotic bodies. The role of apoptosis in tissue-damaging effects induced by these venoms requires further studies.

In conclusion, this is a first-hand investigation showing the potential cytotoxic action and the apoptotic effect of Bothrops venoms in the $\mathrm{C} 2 \mathrm{C} 12$ cell line. 


\section{ACKNOWLEDGEMENTS}

This study was supported by the General Secretary of Science and Technology, Northeast National University, Project PI 076/05, and National Council of Scientific and Technical Research (CONICET), PIP Project 6298.

\section{REFERENCES}

1. Warrell DA. Clinical features of envenoming from snake bites. In: Bon C, Goyffon M, editors. Envenomings and their treatments. Lyon: Fondation Marcel Merieux; 1996. p. 63-76.

2. White J. Clinical toxicology of snakebite in Australia and New Guinea. In: Meier $\mathrm{J}$, White $\mathrm{J}$, editors. Handbook of clinical toxicology of animal venoms and poisons. Florida: CRC Press; 1995. p. 595-617.

3. Acosta de Pérez OC, Koscinzuk P, Teibler P, Sánchez Negrete M, Ruiz R, Maruñak S, Bogarín G. Actividades hemorrágica y edematizante y alteraciones histológicas en almohadilla plantar del ratón inducidas por venenos de serpientes de los géneros Bothrops y Crotalus de Argentina. Toxicon. 1998;36(8):1165-72.

4. Bustillo S, Lucero H, Leiva LC, Acosta OC, Gorodner JO. Citotoxicity of Bothrops alternatus venom measured by an in vitro leukocytes culture assay. Rev Med. 2004; Suppl 2:229-30.

5. Bustillo S, Merino LA, Leiva LC, Acosta OC, Bal de Kier E, Gorodner JO. Antimicrobial activity of Bothrops alternatus venom from the northeast of Argentina. Biocell. 2005;29:238.

6. Milani Jr R, Jorge MT, de Campos FP, Martins FP, Bousso A, Cardoso JL, Ribeiro LA, Fan HW, França FO, Sano-Martins IS, Cardoso D, Fernandes Cl, Fernandes JC, Aldred VL, Sandoval MP, Puorto G, Theakston RD, Warrell DA. Snake bites by the jararacuçu (Bothrops jararacussu): clinicopathological studies of 29 proven cases in São Paulo state, Brazil. Q J Med. 1997;90(5):323-34. 
7. Otero R, Gutierrez J, Mesa MB, Duque E, Rodryguez O, Arango JL, Gomez F, Torof A, Canoe F, Rodryguez LM, Caro E, Martinez J, Comejo W, Gomez LM, Uribe FL, Cardenas S, Nuez V, Diaz A. Complications of Bothrops, Porthidium, and Bothriechis snakebites in Colombia. A clinical and epidemiological study of 39 cases attended in a university hospital. Toxicon. 2002;40:1107-14.

8. Azevedo-Marques MM, Cupo P, Coimbra TM, Hering SE, Rossi MA, Laure CJ. Myonecrosis, myoglobinuria and acute renal failure induced by South American rattlesnake (Crotalus durissus terrificus) envenomation in Brazil. Toxicon. 1985;23(4):631-6.

9. Acosta de Pérez $O$, Koscinzuk $P$, Sánchez Negrete $M$, Teibler $P$, Ruiz R. Efectos del veneno de Bothrops alternatus de Argentina sobre músculo y distintos órganos en ratones. Acta Physiol Pharmacol Ther Latinoam. 1996;46(2):97-102.

10. Teibler P, Acosta de Pérez O, Maruñac S, Ruiz R, Koscinzuk P, Sánchez Negrete M, Mussart de Coppo N. Lesiones locales y sistémicas inducidas por veneno de Bothrops alternatus (víbora de la cruz) de Argentina. Acta Toxicol Argent. 1999;7(1):7-10.

11. Omran MAA, Fabb SA, Dickson G. Biochemical and morphological analysis of cell death induced by Egyptian cobra (Naja haje) venom on cultured cells. J Venom Anim Toxins incl Trop Dis. 2004;10(3):219-41.

12. Damico DC, Nascimento JM, Lomonte B, Ponce-Soto LA, Joazeiro PP, Novello JC, Marangoni S, Collares-Buzato CB. Cytotoxicity of Lachesis muta muta snake (bushmaster) venom and its purified basic phospholipase A2 (LmTX-I) in cultured cells. Toxicon. 2007;49(5):678-92.

13. Angulo $\mathrm{Y}$, Lomonte $\mathrm{B}$. Differential susceptibility of $\mathrm{C} 2 \mathrm{C} 12$ myoblasts and myotubes to group II phospholipase A2 myotoxins from crotalid snake venoms. Cell Biochem Funct. 2005;23(5):307-13.

14. Bieber AL, Ziolkowski C, d' Avis PA. Rattlesnake toxins alter development of muscle cells in culture. Ann NY Acad Sci. 1994;710:126-41.

15. Bruses JL, Capaso J, Katz E, Pilar G. Specific in vitro biological activity of snake venom myotoxins. J Neurochem. 1993;60(3):1030-42. 
16. Incerpi $S$, de Vito $\mathrm{P}$, Luly $\mathrm{P}$, Rufini $\mathrm{S}$. Effect of ammodytin $L$ from Vipera ammodytes on L-6 cells from rat skeletal muscle. Biochim Biophys Acta. 1995;1268(2):137-42.

17. Lomonte B, Angulo Y, Rufini S, Cho W, Giglio JR, Ohno M, Daniele JJ, Geoghegan P, Gutierrez JM. Comparative study of the cytolytic activity of myotoxic phospholipases A2 on mouse endothelial (tEnd) and skeletal muscle (C2C12) cells in vitro. Toxicon. 1999;37(1):145-58.

18. Moravec R, Riss T. Assay systems for detecting apoptosis and cell death. Promega notes. 1998;68:13-8.

19. Georges B, Galland S, Rigault C, Le Borgne F, Demarquoy J. Beneficial effects of L-carnitine in myoblastic $\mathrm{C} 2 \mathrm{C} 12$ cells. Interaction with zidovudine. Biochem Pharmacol. 2003;65(9):1483-8.

20. Araya C, Lomonte B. Antitumor effects of cationic synthetic peptides derived from Lys49 phospholipase A2 homologues of snake venoms. Cell Biol Int. 2007;31(3):263-8.

21. Bonfim VL, Ponce-Soto LA, Novello JC, Marangoni S. Cytotoxic action in myoblasts and myotubes (C2C12) and enzymatic characterization of a new phospholipase $\mathrm{A} 2$ isoform $(\mathrm{Bj}-\mathrm{V})$ from Bothrops jararacussu venom. Protein and Peptide Letters. 2006;13(7):707-13.

22. Lomonte B, Angulo $\mathrm{Y}$, Santamaria $\mathrm{C}$. Comparative study of synthetic peptides corresponding to region 115-129 in Lys49 myotoxic phospholipases A2 from snake venoms. Toxicon. 2003;42(3):307-12.

23. Villalobos JC, Mora R, Lomonte B, Gutiérrez JM, Angulo Y. Cytotoxicity induced in myotubes by a Lys49 phospholipase A2 homologue from the venom of the snake Bothrops asper: evidence of rapid plasma membrane damage and a dual role for extracellular calcium. Toxicol In Vitro. 2007;21(8):1382-9.

24. Spector DL, Goldman RD, Leinwand LA. Morphological assessment of cell death. In: Spector DL, Goldman RD, Leinwand LA. Cells, a laboratory manual, in culture and biochemical analysis of cells. NY: Cold Spring Harbor Laboratory Press; 1997. p. 15.3-15.10. 2 vol. 
25. Gutiérrez JM, Ownby CL. Skeletal muscle degeneration induced by venom phospholipases A2: insights into the mechanisms of local and systemic myotoxicity. Toxicon. 2003;42(8)915-31.

26. Collares-Buzato CB, de Paula le Sueur L, da Cruz-Hofling MA. Impairment of the cell-to-matrix adhesion and cytotoxicity induced by Bothrops moojeni snake venom in cultured renal tubular epithelia. Toxicol Appl Pharmacol. 2002;181(2):12432.

27. Oliveira JCR, de Oca HM, Duarte MM, Diniz CR, Fortes-Dias CL. Toxicity of South American snake venoms measured by an in vitro cell culture assay. Toxicon. 2002;40(3):321-5.

28. Bultron E, Thelestam M, Gutierrez J. Effects on cultured mammalian cells of myotoxin III, a phospholipase A2 isolated from Bothrops asper (terciopelo) venom. Biochim Biophys Acta. 1993;1179(3):253-9.

29. Lomonte B, Tarkowski A, Hanson LA. Broad cytolytic specificity of myotoxin II, a lysine-49 phospholipase A2 of Bothrops asper snake venom. Toxicon. 1994;32(11):1359-69.

30. Ponce-Soto LA, Lomonte B, Gutiérrez JM, Rodrigues-Simioni L, Novello JC, Marangoni S. Structural and functional properties of BaTX, a new Lys49 phospholipase A2 homologue isolated from the venom of the snake Bothrops alternatus. Biochim Biophys Acta. 2007;1770(4):585-93.

31. Araki S, Ishida T, Yamamoto T, Kaji K, Hayashi H. Induction of apoptosis by hemorrhagic snake venom in vascular endotelial cells. Biochem Biophys Res Commun. 1993;190(1):148-53.

32. Tamieti BP, da Matta RA, Cogo JC, Silva NS, Mittmann J, Pacheco-Soares C. Cytoskeleton, endoplasmic reticulum and nuclear alterations in cho-k1 cell line after Crotalus durissus terrificus (South American Rattlesnake) venom treatment. J Venom Anim Toxins incl Trop Dis. 2007;13(1):56-68.

33. Mora R, Maldonado A, Valverde B, Gutierrez JM. Calcium plays a key role in the effects induced by a snake venom Lys49 phospholipase as homologue on $A[2]$ lymphoblastoid cell line. Toxicon. 2006;47(1):75-86. 
34. Mora R, Valverde B, Díaz C, Lomonte B, Gutiérrez JM. A Lys49 phospholipase A2 homologue from Bothrops asper snake venom induces proliferation, apoptosis and necrosis in a lymphoblastoid cell line. Toxicon. 2005;45(5):651-60.

35. Diaz C, Valverde L, Brenes O, Rucavado A, Gutierrez JM. Characterization of events associated with apoptosis/anoikis induced by snake venoms metalloproteinase BaP1 on human endothelial cells. J Cell Biochem. 2005;94(3): $520-8$.

36. Masuda S, Hayashi H, Araki S. Two vascular apoptosis-inducing proteins from snake venom are members of the metalloprotease/disintegrin family. Eur J Biochem. 1998;253(1):36-41.

37. Trummal K, Tonismagl K, Siigur E, Aaspollu A. A novel metalloprotease from Vipera lebetina venom induces human endothelial cell apoptosis. Toxicon. 2005,46(1):46-61.

38. Wu WB, Changa SC, Liau MY, Huang TF. Purification, molecular cloning and mechanism of action of graminelysin I, a snake-venom-derived metalloproteinase that induces apoptosis of human endothelial cells. Biochem J. 2001;357(3):719-28

39. Silva RJ, Silva MG, Vilela LC, Fecchio D. Antitumor effect of Bothrops jararaca venom. Mediators Inflamm. 2002;11(2):99-104.

40. Son DJ, Park MH, Chae SJ, Moon SO, Lee JW, Song HS, Moon DC, Kang SS, Kwon YE, Hong JT. Inhibitory effect of snake venom toxin from Vipera lebetina turanica on hormone-refractory human prostate cancer cell growth: induction of apoptosis through inactivation of nuclear factor KB. Mol Cancer Therapeutics. 2007;6:675-83.

41. Yang RS, Tang $\mathrm{CH}$, Chuang WJ, Huang TH, Peng HC, Huang TF, Fu WM. Inhibition of tumor formation by snake venom disintegrin. Toxicon. 2005;45(5):661-9. 